Marek Rezler

(Poznań)

dr, marek.rezler@gmail.com

ORCID iD: 0000-0001-5059-647X

\title{
Materiały do dziejów Związku Weteranów Powstań Narodowych RP 1914-1921 i Związku Powstańców Wielkopolskich 1918-1919 w zasobie Archiwum Państwowego w Poznaniu
}

Odwiecznym problemem archiwistów i korzystających z akt było połączenie ochrony zasobu z umiejętnym udostępnianiem i korzystaniem. Najbardziej racjonalne było wykonanie reprodukcji i udostępnianie kopii zamiast oryginału dokumentu; przez wiele dziesięcioleci najpopularniejsze było mikrofilmowanie, co tylko w części zapewniało ochronę oryginału i dostępność kopii. Przełomem stała się powszechna komputeryzacja i możliwość digitalizacji zasobów archiwalnych. Od mniej więcej dwudziestu lat jest to najczęściej spotykana i najbardziej racjonalna forma reprodukowania i udostępniania materiałów archiwalnych.

\section{Projekt digitalizacji akt dotyczących powstania wielkopolskiego 1918-1919}

Od 2003 r. w Archiwum Państwowym w Poznaniu rozpoczęto systematyczną digitalizację najważniejszych dokumentów z zasobu Archiwum, m.in. akt miejskich. W trzy lata później podjęto bardzo szeroko zaplanowaną inicjatywę, przewidującą digitalizację i umieszczenie $\mathrm{w}$ sieci podstawowych materiałów archiwalnych dotyczących zaangażowania Wielkopolan w powstaniach lat: 1830-1831, 1848, 1863-1864 oraz 1918-19191. Zbliżająca się w 2008 roku 90. rocznica wybuchu powstania wielkopolskiego 1918-1919 ukierun-

${ }^{1}$ H. Krystek, Digitalizacja materiatów archiwalnych w Archiwum Państwowym w Poznaniu, „Poznański Rocznik Archiwalno-Historyczny” 2012, nr 15, s. 3-50; tegoż, Digitalizacja materia- 
kowała szczególne zainteresowania rejestrujące i digitalizujące w stronę tego wydarzenia. Projekt przewidywał zeskanowanie około pięćdziesięciu tys. stron/kart dokumentów zawartych w zasobach Archiwum Państwowego w Poznaniu, w oddziałach w Gnieźnie, Koninie i Pile oraz Archiwum Akt Nowych, Archiwów Państwowych w Bydgoszczy, Katowicach, Kaliszu, Lesznie i w Zielonej Górze.

Realizacja tego ambitnego planu natrafiła jednak na trudności finansowe, co zmusiło inicjatorów do zmiany kierunku działania i metody. Skorzystano z pomocy lokalnych sponsorów, co pozwoliło na opublikowanie w latach 2008-2009 czterech płyt zawierających materiały związane z powstaniem wielkopolskim na danym terenie - także skany dokumentów z zasobu Archiwum Państwowego w Poznaniu:

- Źródła do dziejów powstania wielkopolskiego na ziemi ostrowskiej ze zbiorów Archiwum Państwowego w Poznaniu (we współpracy z Ostrowskim Towarzystwem Genealogicznym) ze środków Stowarzyszenia Fundusz Grantowy Dobrego Sąsiedztwa dla Ostrowa Wielkopolskiego;

- Źródła do dziejów powstania wielkopolskiego w południowej Wielkopolsce w zbiorach Archiwum Państwowego w Kaliszu i Archiwum Państwowego w Poznaniu (wspólna praca obydwu Archiwów);

- Źródła do dziejów powstania wielkopolskiego na ziemi pobiedziskiej ze zbiorów Archiwum Państwowego w Poznaniu, Biblioteki Uniwersyteckiej w Poznaniu oraz zbiorów prywatnych-opracowanie Archiwum Państwowego w Poznaniu we współpracy z Urzędem Miasta i Gminy Pobiedziska;

- Źródła do dziejów powstania wielkopolskiego w południowo-zachodniej Wielkopolsce w zbiorach Archiwum Państwowego w Lesznie i Archiwum Państwowego w Poznaniu - praca obydwu Archiwów, we współpracy ze starostwem powiatowym w Lesznie.

Każda płyta opracowana jest $\mathrm{w}$ formie prezentacji $\mathrm{w}$ programie Power Point, zawierającej także artykuły problemowe dotyczące istoty digitalizacji dokumentów i przebiegu powstania na danym terenie.

Równocześnie stopniowo przystąpiono do umieszczania zdigitalizowanych już materiałów w sieci, w ramach Wielkopolskiej Biblioteki Cyfrowej.

łów archiwalnych w Archiwum Państwowym w Poznaniu, http://www.poznan.ap.gov.pl/index. php?option=com_content\&view=article\&id=131\&limitstart=5 (dostęp: 7.06.2019). 


\section{Organizacje zrzeszające uczestników powstania wielkopolskiego $\mathrm{w}$ okresie międzywojennym}

W Drugiej Rzeczypospolitej ruch kombatancki był bardzo zróżnicowany i rozproszony, choć organizowano akcje scaleniowe i starano się łączyć uczestników różnych walk zbrojnych, zwłaszcza działających na tym samym lub zbliżonym obszarze. Często były to organizacje istniejące krótko, prawie efemerydy, pozostające ze sobą w sporze i rywalizacji. Ich możliwości były związane $\mathrm{z}$ tendencjami politycznymi w państwie, powodującymi wartościowanie weteranów, satysfakcjonowały pewne środowiska, irytowały zaś i budziły frustrację innych, co było widoczne także we wzajemnych kontaktach i stosunkach międzyorganizacyjnych.

Powstańcy wielkopolscy początkowo zrzeszeni byli w wielu różnych organizacjach kombatanckich, m.in.: w Związku Towarzystw Powstańców i Wojaków, Towarzystwie Powstańców i Wojaków, Związku Uczestników Powstań Narodowych. W 1921 r. powstał Związek Powstańców Wielkopolski, równolegle przystąpiono do tworzenia Towarzystwa Uczestników Powstania z roku 1919, które osiem lat później weszło w skład Związku Weteranów Powstań Narodowych Rzeczypospolitej Polskiej². W maju 1922 r. powołano Związek Towarzystw Powstańców i Wojaków na Województwo Poznańskie i równolegle podobną organizację na województwo pomorskie, a następnie (zrzeszającą już tylko powstańców wielkopolskich) na Śląsku. Podobną organizację powołano w Bydgoszczy. W styczniu 1938 r. nastąpiło przekształcenie organizacji w Związek Powstańców Wielkopolskich, działający w strukturach Federacji Polskich Związków Obrońców Ojczyzny, funkcjonujący do wybuchu II wojny światowej. Jedną z kluczowych pozycji w działalności Związku zajmowała Komisja Weryfikacyjna, która ściśle współdziałała z Referatem Historycznym przy Dowództwie Okręgu Korpusu nr VII w Poznaniu. W sumie w 1937 r. ZWPN zrzeszał ponad 23200 członków, zorganizowanych w trzech okręgach: Poznańskim, Pomorskim i Śląskim; Zarząd Okręgu Poznańskiego wykonywał równocześnie obowiązki Zarządu Głównego. Organami prasowymi organizacji były pisma: "Za Wolność” (1927), "Jutro” (1936-1938), "Głos Powstańca Wielkopolskiego” (1938-1939) i „Powstaniec Wielkopolski" (1933, 1937-1939)3.

W 1946 r. Związek Powstańców Wielkopolskich został reaktywowany, działał w mniejszej niż przed wojną liczbie kół i objął swym zasięgiem wete-

2 J. Łuczak, Organizacje kombatanckie uczestników Powstania Wielkopolskiego 1918-1919, [w:] tegoż, Chorązwie weteranów Powstania Wielkopolskiego 1918-1919 w zbiorach Wielkopolskiego Muzeum Wojskowego, Poznań 1999, s. 9 i n; A. Wierzejewski, Ruch kombatancki w Wielkopolsce. Zarys dziejów do 1989 roku, Poznań 1989.

${ }^{3}$ Wszystkie wydane numery tych pism są już zdigitalizowane i dostępne w sieci. 
ranów powstania, którzy zamieszkali na Ziemiach Zachodnich i Północnych. Początkowo zamierzano kontynuować działalność przedwojenną, ale nowe realia polityczne zmusiły do modyfikacji form i metod funkcjonowania, a w 1949 r. nastąpiło przymusowe włączenie Związku do nowo utworzonego Związku Bojowników o Wolność i Demokrację, gdzie zebrano środowiska zrzeszające uczestników różnych walk - także w Wielkopolsce w latach 1918-1919 i na Górnym Śląsku 1919-1921. Działalność tych ośrodków wygasała $\mathrm{w}$ miarę odchodzenia kolejnych weteranów - choć zachowany został kontakt $\mathrm{z}$ ich rodzinami.

\section{Zawartość i ocena zespołu}

Wiosną 2011 r. Dyrekcja Archiwum Państwowego w Poznaniu podjęła decyzję o wykonaniu spisu i weryfikacji wszystkich najważniejszych dokumentów dotyczących powstania wielkopolskiego, znajdujących się $\mathrm{w}$ zasobie Archiwum Państwowego w Poznaniu i w poszczególnych oddziałach - jako pomoc naukową przewidzianą do umieszczenia w przyszłości w Internecie ${ }^{4}$. Po wytypowaniu zespołów i teczek postanowiono w pierwszej kolejności opracować materiał najobszerniejszy, zawarty w zespole nr 884: Związek Powstańców Wielkopolskich. Praca nad tym materiałem trwała do połowy marca 2015 r., została zawarta w 13960 rekordach zestawionych w programie Excel. W trakcie pracy zastosowano metodę wyróżnienia dokumentów podstawowych, kluczowych dla Związku kolorem czerwonym, dokumentów umieszczonych w niewłaściwej teczce - zielonym, ze wskazaniem miejsca, do którego należałoby je przenieść.

Równolegle, niżej podpisany, na zlecenie Dyrekcji Archiwum przeprowadził weryfikację fotografii dotyczących powstania, zawartych w zasobie Archiwum - także poprawności treści podpisów. Przeanalizowano zdjęcia z powstania, kombatanckie i rodzinne, m.in. zespół 5292, sygn. 17: Archiwum Goetzendorf-Grabowskich, oraz zespoły: 1409 (zbiór fotografii z lat 19191944) i 559 - Album pamiątkowy Kismanowskiego. Planowane początkowo opracowanie albumu zawierającego fotografie powstańcze okazało się jednak niemożliwe ze względu na zbyt małą liczbę fotografii nowych, dotąd nieznanych i dobrej jakości ${ }^{5}$.

\footnotetext{
${ }^{4}$ Obszerny wykaz zespołów i poszczególnych sygnatur można już dziś uzyskać w wyniku korzystania z wyszukiwarki szukajwarchiwach.pl.

${ }^{5}$ W podobnej sytuacji znalazł się Bogusław Polak, który w wydanym w 2010 r. w Koszalinie albumie Wojsko Wielkopolskie 1919-1920 musiał niekiedy posiłkować się faksymiliami dokumentów, zwłaszcza rozkazów dziennych Dowództwa Głównego Sił Zbrojnych w byłym zaborze pruskim. Ostatnio jednak strony internetowe założone przez miłośników historii powstania wielkopolskiego i rekonstruktorów zaczęły ujawniać znakomite, nieznane dotąd zdjęcia znaj-
} 
Zbiór akt dotyczących Związku Powstańców Wielkopolskich stanowi (według oceny Czesława Skopowskiego z 1961 r.) około trzydzieści proc. dokumentów pierwotnego zasobu ${ }^{6}$. Są to materiały po kampanii wrześniowej przejęte przez Niemców, przypuszczalnie analizowane $\mathrm{w}$ archiwum w Oliwie, o czym świadczą odręczne tłumaczenia na język niemiecki tytułów niektórych dokumentów, umieszczane na oryginałach. Potem akta te znajdowały się w Związku Radzieckim, skąd wróciły do Polski i w Poznaniu zostały uporządkowane. W miarę upływu czasu i zdobywania kolejnych materiałów, były one dołączane do już istniejących - co sprawiło, że zespół rozrósł się z 363 w 1961 r. do obecnych 402 j.a. Materiał jest uporządkowany, a w 2008 r. cały zespół został zdigitalizowany.

Zespół 884 Związek Powstańców Wielkopolskich 1918-1919 składa się z 402 j.a. Brakuje teczki nr 369. Jednak treść teczki nr 1 (Organizacja ZPW w latach 1945-1949) jest zbieżna $\mathrm{z}$ opisem w inwentarzu teczki brakującej. Niewykluczone więc, że nastąpiło albo przenumerowanie teczki, albo wprowadzenie omyłkowo nowego numeru teczki już raz zarejestrowanej. Nie można jednak wykluczyć, że zaginęły materiały o podobnej treści. Obecnie trudno jednoznacznie wyjaśnić tę anomalię.

Zespół zawiera materiały Związku Weteranów Powstań Narodowych R.P. 1914/19 (ZWPN) i Związku Powstańców Wielkopolskich 1918-1919 (ZPW), sporadycznie też dokumenty wydane przez Towarzystwo Powstańców Wielkopolskich z roku 1918-1919 i Federację Polskich Związków Obrońców Ojczyzny.

Teczki 1 i następne zawierają statury i okólniki Zarządu Głównego ZWPN.

18-33. Akta weryfikacyjne.

34-119. Dokumenty różne (m.in. zawierające oznaki zainteresowania Niemców dokumentami).

120-363. Akta delegatów powiatowych i kół Związku, ułożone alfabetycznie.

364-379. Dokumenty różne, dotyczące zjazdów, spraw socjalnych itd.

380-387. Współdziałanie kół ZPW w latach 1946-1949.

388-402. Materiały różne, najpewniej dołączane stopniowo, w miarę ich pozyskiwania.

\footnotetext{
dujące się w zbiorach prywatnych, co daje nadzieję na opracowanie nowego albumu w przyszłości. Pojawiła się tu jednak konieczność uważnej analizy tych fotografii, gdyż członkowie grup rekonstrukcyjnych, którzy osiągnęli wysoki stopień zgodności swych mundurów z realiami epoki, zaczęli robić sobie zdjęcia, technicznie stylizowane na wykonane przed ponad dziewięćdziesięciu laty.

${ }^{6}$ Archiwum Państwowe w Poznaniu, zespół nr 884, Związek Powstańców Wielkopolskich, wstęp do inwentarza.
} 


\section{Oceny i propozycje}

Zespół zawiera dokumenty o bardzo różnej wartości i znaczeniu dla badań nad dziejami powstania wielkopolskiego 1918-1919 i funkcjonowania organizacji kombatanckich zrzeszających uczestników tych wydarzeń. Obok statutów i dokumentów programowych - kluczowych dla prac nad ZWPN i ZPW, w poszczególnych teczkach jest wiele informacji szczegółowych i przyczynkarskich. Przeważa bieżąca korespondencja Zarządów Głównych obydwu organizacji i poszczególnych kół (oryginały pism przychodzących i kopie odpowiedzi). Jednak ilość materiałów jest nierówna - choćby $w$ aktach poszczególnych kół obydwu związków, co wynika z niezachowania się całości dokumentacji. Szczególną wartość dla badań biograficznych mają teczki 31-33, zawierające wykaz zweryfikowanych członków ZWPN (lecz bez pierwszych stu pozycji), a także teczki nr 43-45, zawierające ewidencję członków ZWPN; skany te są już dostępne w sieci, choć nie każdy poszukujący potrzebnej mu informacji, będzie umiał do nich dotrzeć ${ }^{7}$.

Jak wspomniano, niektóre dokumenty świadczą o zainteresowaniu w latach 1939-1945 niemieckich organów bezpieczeństwa powstańcami, co zostało wyrażone odręcznymi tłumaczeniami tytułów niektórych dokumentów. W zespole jest również teczka nr 119, zawierająca „Listę członków Związku Powstańców Wielkopolskich przesłaną przez hitlerowców SD - Torun do SD - Leitabschnitt - Poznań". W gruncie rzeczy jest to zestaw dokumentów wyjętych z akt związkowych, zawierających wykaz członków niektórych kół i materiały dotyczące pojedynczych powstańców - zatem wyraźnie ukierunkowany. Znajdujemy tu potwierdzenie praktyki stosowanej w czasie okupacji przez władze hitlerowskie: wbrew spotykanym niekiedy sądom, nie poszukiwano absolutnie wszystkich uczestników powstania wielkopolskiego, lecz weteranów najbardziej zasłużonych i aktywnych. Natomiast za udział w powstaniu rozliczano także mniej znaczących powstańców, w przypadku ich aresztowania za udział w pracy organizacji konspiracyjnej po $1939 \mathrm{r}$.

Od strony merytorycznej Zespół jest kopalnią interesujących, wiarygodnych szczegółów, jednak wymagających uważnej analizy i znajomości tematu, gdyż zachowane niekiedy pojedyncze dokumenty dotyczące danej osoby czy sprawy mogą doprowadzić do niekompletnych lub mylących wniosków. Konieczne jest zatem porównanie uzyskanych informacji z danymi zachowanymi w innych zespołach. Zawarty w zespole materiał pozwala jednak uzyskać miarodajną ocenę dotyczącą stosunków pomiędzy poszczególnymi organizacjami kombatanckimi, mechanizmów weryfikowania weteranów powstania czy konfliktów i rywalizacji (nawet przypadków swoistej, wzajemnie uprawianej dywersji). Interesujące są relacje z lustracji i uroczystości organizowanych

\footnotetext{
${ }^{7}$ Zob. m.in.: http://szukajwarchiwach.pl/53/884/0/1/45/\#tabJednostka (dostęp: 7.06.2019).
} 
przez Związek i poszczególne koła. W miarę upływu czasu widoczne są problemy z dostosowaniem się ZPW do zmiennej sytuacji politycznej, a po II wojnie światowej, w nowych realiach ustrojowych - rozpaczliwa walka o utrzymanie samodzielności organizacji, zmuszająca do upokarzających koncesji na rzecz nowych realiów politycznych. Wiele jest opisów uroczystości patriotycznych, ale też relacji z konfliktów międzyorganizacyjnych i pomiędzy poszczególnymi członkami Związku. Zdarzają się sytuacje anegdotyczne i zaskakujące, jak sprawa okoliczności pozbawienia w 1938 r. prezesa ZPW gen. Kazimierza Raszewskiego członkostwa organizacji, czy... rozesłania przez zarząd jednego z kół zaproszeń na zabawę karnawałową w języku niemieckim. Takich ciekawostek i smaczków w poszczególnych teczkach jest wiele - ale wymagają uważnej analizy i oceny, bez doszukiwania się elementów taniej sensacji.

Bardzo ważne są zachowane $\mathrm{w}$ zespole informacje o charakterze socjalnym i ekonomicznym. W międzywojennym dwudziestoleciu ze względów politycznych powstańcy wielkopolscy stali nisko w hierarchii związków kombatanckich, co znalazło wyraz także $\mathrm{w}$ ich bardzo trudnym położeniu materialnym, a w okresie kryzysu ekonomicznego po 1929 r. - wręcz bezrobociu i nędzy ${ }^{8}$. Władze ZWPN i ZPW starały się wszelkimi sposobami pomóc weteranom $\mathrm{w}$ zdobyciu choćby tymczasowej pracy, a niektóre podania i prośby o wsparcie dla uczestników powstania - wtedy ludzi przeważnie trzydziesto-, czterdziestoparoletnich, a więc $w$ pełni sił - są wstrząsające $w$ treści i formie.

Badacz dziejów militarnych powstania wielkopolskiego znajdzie w zespole sporo relacji i opisów wydarzeń - jednak na ogół mało oryginalnych, o różnej wartości poznawczej. Znajdują się one głównie w aktach personalnych, w dokumentacji weryfikacyjnej, niekiedy w referatach okolicznościowych. Zatem pod względem merytorycznym dla historyka powstania będzie to materiał kolejnego szeregu, zwłaszcza po dokumentacji zawartej w zespole 1144: Dowództwo Okręgu Generalnego w Poznaniu, sygn. 1-79.

W 1978 r. ukazał się w Poznaniu, na marginesie wystawy okolicznościowej w Muzeum Narodowym, katalog Źródła i materiały do dziejów powstania wielkopolskiego i Wojsk Wielkopolskich 1918-1919, redagowany przez Tadeusza Jeziorowskiego. Przez szereg lat był to dla historyków podstawowy zbiór in-

${ }^{8}$ Obszernie na ten temat zob. m.in.: M. Olszewski, O powstańcach wielkopolskich $w$ II Rzeczypospolitej... nieco inaczej, „Wielkopolski Powstaniec” 2005, s. 42 i n; G. Wojciechowski, Jeszcze raz o sytuacji powstańców wielkopolskich w II Rzeczypospolitej, „Wielkopolski Powstaniec” 2006, s. 39 i n.

${ }^{9} \mathrm{~W}$ pierwszych czterech teczkach zawarte są rozkazy dzienne Dowództwa Głównego Sił Zbrojnych byłego Zaboru Pruskiego (z nielicznymi zachowanymi załącznikami), w dwu kolejnych rozkazy Dowództwa Frontu Wielkopolskiego w 1920 r., następnie niektóre rozkazy Komendy Miasta Poznania z 1920 r., a w teczce nr 15 rozkazy dzienne Straży Ludowej b. zaboru pruskiego (zachowane niektóre). Ponadto podobne dokumenty najwyższego szczebla przechowywane są w Pile, w tamtejszym Oddziale Archiwum Państwowego w Poznaniu, w aktach miast Chodzież, Czarnków i Margonin oraz starostwa powiatowego w Czarnkowie. 
formacji dotyczących materiałów związanych z powstaniem, przechowywanych w muzeach i bibliotekach poznańskich i w niektórych muzeach regionalnych $\mathrm{w}$ Wielkopolsce. Zamieszczono tam również ogólny przegląd dokumentów przechowywanych w Archiwum Państwowym w Poznaniu. Z czasem jednak zawartość tego informatora okazała się niewystarczająca i w 2003 r. Towarzystwo Pamięci Powstania Wielkopolskiego 1918/1919 opublikowało Powstanie wielkopolskie 1918-1919. Katalog źródeł i materiałów pod redakcją Stanisława Sierpowskiego. Ów „niebieski katalog” (jak od koloru okładki badacze dziejów powstania książkę nazywają) do dziś jest podstawą informacji na ten temat, choć w dużej mierze zdezaktualizowaną; zresztą od początku podstawowym niedostatkiem katalogu jest brak informacji o zasobie choćby kluczowego dla tematu Centralnego Archiwum Wojskowego ${ }^{10}$. Od tego czasu pojawiły się nowe źródła informacji, ważnym źródłem danych stał się także Internet.

Po trzynastu latach od opublikowania katalogu Sierpowskiego najwyraźniej zachodzi potrzeba opracowania (niekoniecznie w formie drukowanej) aktualnego zestawu informacji o materiałach dotyczących powstania wielkopolskiego, przechowywanych w kraju i za granicą - zwłaszcza w zbiorach Instytutu Polskiego i Muzeum im. Gen. Sikorskiego w Londynie, w archiwach Wielkiej Brytanii, Francji i Niemiec. Inicjatywa skanowania, spisywania i weryfikacji dokumentów dotyczących powstania w Archiwum Państwowym w Poznaniu (z Oddziałami) i w kraju, jest ważnym krokiem w udostępnianiu materiałów, a jednocześnie służy informacji i ochronie zasobów archiwalnych - zgodnie z aktualnymi tendencjami i zasadami. Praca ta będzie kontynuowana.

\section{Bibliografia}

Materiały archiwalne

Archiwum Państwowe w Poznaniu, zespół nr 884: Związek Powstańców Wielkopolskich.

\section{Opracowania}

H. Krystek, Digitalizacja materiałów archiwalnych w Archiwum Państwowym w Poznaniu, „P Poznański Rocznik Archiwalno-Historyczny" 2012, nr 15.

H. Krystek, Digitalizacja materiałów archiwalnych w Archiwum Państwowym w Poznaniu, http:// www.poznan.ap.gov.pl $/$ index.php?option $=$ com_content\&view $=$ article\&id $=131 \&$ limitstart=5 (dostęp: 7.06.2019).

J. Łuczak, Organizacje kombatanckie uczestników Powstania Wielkopolskiego 1918-1919, [w:] tegoż, Choragzie weteranów Powstania Wielkopolskiego 1918-1919 w zbiorach Wielkopolskiego Muzeum Wojskowego, Poznań 1999.

${ }^{10}$ Katalog jest rozprowadzany przez Zarząd Główny Towarzystwa Pamięci Powstania Wielkopolskiego 1918/1919, w formacie pdf jest dostępny też w sieci: http:/ / dlibra.kul.pl/dlibra/docmetadata?from=rss\&id=21039 (dostęp: 7.06.2019). 
M. Olszewski, O powstańcach wielkopolskich w II Rzeczypospolitej... nieco inaczej, „Wielkopolski Powstaniec" 2005.

A. Wierzejewski, Ruch kombatancki w Wielkopolsce. Zarys dziejów do 1989 roku, Poznań 1989.

G. Wojciechowski, Jeszcze raz o sytuacji powstańców wielkopolskich w II Rzeczypospolitej, „Wielkopolski Powstaniec" 2006.

Powstanie wielkopolskie 1918-1919. Katalog źródet i materiatów, red. S. Sierpowski, Poznań 2003.

Źródła i materiały do dziejów powstania wielkopolskiego i Wojsk Wielkopolskich 1918-1919, red. T. Jeziorowski, Poznań 1978.

Marek Rezler

\title{
Związek Weteranów Powstań Narodowych RP 1914-1921 i Związek Powstańców Wielkopolskich 1918-1919 w świetle materiałów Archiwum Państwowego w Poznaniu
}

\section{Streszczenie}

W 2011 r., z okazji zbliżającej się, setnej rocznicy wybuchu powstania wielkopolskiego, Archiwum Państwowe w Poznaniu przystąpiło do rejestrowania i digitalizacji dokumentów dotyczących powstania, znajdujących się w zasobach Archiwum. Szczególnie interesujący jest zespół nr 884: Związek Powstańców Wielkopolskich, w którym zgromadzono dokumenty niemal wszystkich związków kombatanckich zrzeszających weteranów wielkopolskich wydarzeń z lat 1918-1919. Zachowany materiał, zebrany w 402 j.a. (13 960 rekordów spisu), choć nierówny merytorycznie, pozwala zorientować się wielokierunkowo $\mathrm{w}$ realiach środowiska $\mathrm{w}$ okresie (zwłaszcza) międzywojennym. Spis zespołu został zakończony i jest gotowy do udostępnienia w sieci.

Słowa kluczowe: powstanie wielkopolskie, związki kombatanckie, Archiwum Państwowe w Poznaniu

Marek Rezler

\section{Polish Association of the Veterans of National Uprisings 1914-1921 and the Association of Greater Poland Uprising Veterans 1918-1919 in the light of the materials of the State Archive in Poznan}

\begin{abstract}
In 2011, to celebrate the upcoming one-hundredth anniversary of the Greater Poland Uprising, the State Archive in Poznań began registering and digitalizing documents regarding the uprising, found in the collection of the Archive. Fond no. 884: "Association of Greater Poland Uprising Veterans" is particularly interesting. It includes documents on nearly all veteran associations uniting veterans of the events in Greater Poland in the years 1918-1919. The preserved material, collected in archival unit 402 (13 960 records on the list), though of varying quality, allows one to gain some knowledge on the operation of the community, especially in the interwar period. The inventory of the fond is now complete and ready to be shared on the Internet.
\end{abstract}

Keywords: Greater Poland Uprising, veteran associations, State Archive in Poznań 